\title{
НАВЧАННЯ ХОРЕОГРАФІЇ ДІТЕЙ МОЛОДШОГО ШКІЛЬНОГО ВІКУ В СУЧАСНИХ ПОЗАШКІЛЬНИХ ЗАКЛАДАХ М. ХАРКОВА
}

\author{
Зозуля К. В. \\ кандидат педагогічних наук, викладач кафедри початкової і професійної \\ освіти, Харківський національний педагогічний університет \\ імені Г. С. Сковороди, м. Харків, Україна
}

У статті подано аналіз відомих художніх колективів, танцювальних та хореографічних гуртків, ансамблів народного, сучасного та спортивно-бального танцю м. Харкова. Установлено, що навчання хореографії дітей молодшого шкільного віку в сучасних позашкільних закладах відбувається в аматорських колективах та у профільних мистецьких установах.

Ключові слова: організація, навчання, хореографія, молодший шкільний вік, позашкільні заклади.

The article examines an analysis of well-known art groups, dance and choreographic clubs, folk, modern and modern sports and ballroom dance ensembles in Kharkiv has been given. It has been established that choreography training for primary school-age children in extracurricular institutions is currently taking place in amateur groups and in specialized art institutions.

Keywords: organization, training, choreography, primary school age, extracurricular institutions.

Сьогодні однією з центральних проблем у педагогіці є проблема формування творчої діяльності дітей, бо виховання людини - одне із головних педагогічних завдань. Необхідність застосування нових педагогічних технологій особистісно зорієнтованої моделі виховання для формування художньо-творчих здібностей дітей відображено в Національній доктрині розвитку освіти в Україні.

Синтезом фізичних та естетичних цінностей $є$ хореографічна діяльність за своєю природою. Це дозволяє вирішувати різні завдання з розвитку молодших школярів, як-от: збереження здоров'я, задоволення художньо-творчих потреб, розвиток креативності, виховання національної свідомості тощо. 3 огляду на це, ми вважаємо актуальним зробити аналіз відомих художніх колективів, танцювальних та хорео- 
Розділ І. Ціннісні орієнтири духовно-інтелектуального виховання, розвиток духовно-інтелектуальних якостей особистості в умовах співпраці й інклюзії

графічних гуртків, ансамблів народного, сучасного та сучасного спортивно-бального танцю м. Харкова.

Сьогодні широко відомими є театр-студія Олексія Литвинова «Горизонт», що працює на базі Харківського Палацу культури залізничників, студія танцю «Litvinoff dance» (генеральний директор Анастасія Суярова), Ансамбль «Щасливе дитинство», що працює на базі Харківського обласного Палацу дитячої та юнацькою творчості (керівником колективу призначено Р. Галенко), «Театр естрадного танцю «Карнавал» - Комунальний заклад «Харківський палац дитячої і юнацької творчості» (художній керівник Марина Білецька), клуб бального танцю «Вояж» (Керівники: Костянтин Бобрусь та Марина Літкє) [4,5].

У театрі-студії «Горизонт» молодших школярів навчають сучасним бальним танцям та дитячій хореографіі. Навчання відбувається на основі авторської програми «Спортивно-бальна хореографія». У клубі бального танцю «Вояж» навчання відбувається з 6 років. До програми навчання включено: вивчення сучасних бальних танців (повільний вальс, фокстрот, квикстеп, танго, румба, самба, ча-ча-ча). Танцювальний колектив працює за авторською програмою «Навчальна програма 3 позашкільної освіти художньо-естетичного напряму гуртка бального танцю «Вояж».

О. Литвинов також відкрив власну студію танцю «Litvinoff dance». У студіє відбувається навчання майже усім танцювальним стилям, які відомі сьогодні (бальні танці, хіп-хоп, jazz-funk, contemporary, сальсо, мамбо, класична хореографія та ін.). До навчання запрошуються діти 33 років. Навчальний процес відбувається виключно за авторськими програмами.

Навчання у ансамблі «Щасливе дитинство» та «Театрі естрадного танцю «Карнавал» відбувається за програмою «Навчальна програма 3 позашкільної освіти художньо-естетичного напряму ансамблю танцю «Щасливе дитинство» та авторською програмою «Навчальна програма 3 позашкільної освіти художньо-естетичного напряму театру естрадного танцю «Карнавал»». Згідно $з$ програмою по закінченню вищого рівня навчання вихованці, які склали кваліфікаційний іспит, отримують спеціальне свідоцтво «Про позашкільну освіту» $[4,5]$.

На території Харківської області діють профільні позашкільні навчально-виховні заклади, які забезпечують умови для всебічного розвитку інтересів дітей, їх нахилів та здібностей і задовольняють потреби з певного напряму діяльності. 
Найбільш відомою хореографічною школою в Харкові є хореографічна школа та єдиний при ній на всій території України дитячий балетний театр. Директором школи сьогодні працює Наталія Олександрівна Ржевська. В хореографічній школі відбувається навчання дітей 6-9 років, яке проходить за авторськими програмами і включає:

- танець - навчання основам хореографії, розвиток артистизму, пластичної фантазії;

- гімнастику — включає розкриття фізичних можливостей, зміцнення організму, здоров'я, виховання професійних даних;

- ритміку і музично-творчу практику — передбачає розвиток музикальності, ритму, ладового слуху, вокальних даних;

- етику: курс «Чесноти», «Азбука театру», «Міфи давніх цивілізацій», котрі спрямовані на виховання інтелекту, духовне формування особистості;

- образотворче мистецтво - до складу якого входить навчання малюванню, розвиток просторової фантазії.

Навчання також включає хор, уроки фортепіано, вокал. Починаючи 3 3-го (1 «балетний» клас) до 8 класу, діти вивчають класичний танець, історико-побутовий, народно-сценічний танець, модерн, музичну літературу, етику: курс «Слов’янська міфологія», «Історія релігії», історію театру, образотворче мистецтво, майстерність актора, фортепіано, музично-творчу практику.

Після закінчення повного курсу навчання Харківська хореографічна школа видає свідоцтво державного зразка, на базі якого можна продовжувати навчання в училищах, інститутах і університетах України та за їі межами [8].

До спеціалізованих мистецьких закладів, які надають початкову хореографічну освіту в м. Харкові належать: Дитяча школа мистецтв № 5 імені Д. О. Дунаєвського, Дитячий заклад «Дитяча школа мистецтв № 6 ім. Г. Жуковського» та Комунальний початковий спеціалізований навчальний заклад «Дитяча школа мистецтв № 6» $[1,2,6]$.

Навчання у Дитячій школі мистецтв № 5 імені Д. О. Дунаєвського проводиться за типовими навчальними планами для шкіл естетичного виховання. При вступі до школи на хореографічне відділення дитина повинна володіти музичним слухом та пам'яттю, почуттям ритму та уміти рухатися під музику, мати музичний слух [2]. 
Розділ І. Ціннісні орієнтири духовно-інтелектуального виховання, розвиток духовно-інтелектуальних якостей особистості в умовах співпраці й інклюзії

Дитячий заклад «Дитяча школа мистецтв № 6 ім. Г. Жуковського» має 4 відділення: музичне, художнє, хореографічне та відділ мультимедіа.

Хореографічне відділення зазначеної школи в своєму складі має два відділи. Це: відділ народної і відділ сучасної хореографії. Кожний із відділів надає учням інформацію про класичний танець, історію мистецтв і профільний предмет (народний чи сучасний танець), у залежності від напряму діяльності.

На хореографічне відділення набирають дітей віком від 6 років, які вже йдуть до 1-го класу закладу загальної середньої освіти. Для молодших школярів при школі діють підготовчі групи хореографічного спрямування. Хореографічне відділення керується Освітньою програмою «Хореографічне мистецтво». Навчання відбувається протягом 8 років, а по закінченню - учень отримує свідоцтво державного зразку [1].

Відбір дітей до хореографічних шкіл проходить на конкурсній основі. Майбутній учень у залежності від віку повинен володіти танцювальними рухами, мати музикальність, відчуття ритму, координаційну пам'ять та мати відповідні фізичні данні (наявність необхідного підйому стопи; амплітуда кроку; достатній рівень гнучкості; навички стрибка; зовнішню сценічність) [8].

Таким чином, узагальнюючи матеріал можна дійти висновку, що навчання хореографії дітей молодшого шкільного віку в сучасних позашкільних закладах м. Харкова відбувається в аматорських колективах та у профільних мистецьких установах. Навчання хореографії в танцювальних та хореографічних гуртках, ансамблях і студіях відбувається на авторських програмах керівників, які складені на основі програм з позашкільної освіти художньо-естетичного напряму. Освітній процес у мистецьких школах здійснюється за типовими освітніми програмами та за авторськими програмами, розробленими на основі типових освітніх програм.

\section{Список використаних джерел:}

1. Дитяча школа мистецтв № 6 ім. Г. Жуковського. веб-сайт. URL : https:// my-shkola.kiev.ua/khoreografichne-viddilennia/pro-khoreografichneviddilennia

2. Дитяча школа мистецтв № 5 імені I. О. Дунаєвського. веб-сайт. URL : http://dshm5.com.ua/ 


\section{Духовно-інтелектуальне виховання і навчання молоді в XXI столітті}

3. Зозуля К. В. «Організація навчання хореографії дітей молодшого шкільного віку в позашкільних закладах України (друга половина XX століття)» : дис... канд. пед. наук: 13.00.01 Харків, 2020. 241 с.

4. Комунальний заклад «Харківський палац дитячої та юнацької творчості Харківської міської ради Харківської області». веб-сайт. URL : http:// dvorec.edu.kh.ua/programi_navchannya/

5. Комунальний заклад «Харківський обласний Палац дитячої та юнацької творчості». веб-сайт. URL : https://firstpalace.kh.ua/

6. Комунальний початковий спеціалізований учбовий заклад Дитяча школа мистецтв № 6. веб-сайт. URL : http://dshi6.kharkov.ua/ua/page/ horeograficheskoe-otdelenie

7. Програма для хореографічної школи, хореографічного відділення початкового спеціалізованого мистецького навчального закладу (школи естетичного виховання. Напрям «Народно-сценічний танець». Уклад. О. М. Тіщенко. Київ, 2012. 48 с.

8. Харківська хореографічна школа. веб-сайт. URL : https://ballet.kharkov. ua/informatsiya/informatsiya-dlya-roditelej/pravila-priema.html 